\title{
Review of Aflatoxin in Pistachio and its Control Strategies MOHAMMAD MORADI ${ }^{1{ }}$ and SEYED REZA FANI ${ }^{2}$
}

1- Pistachio Research Center, Horticultural Sciences Research Institute, Agricultural Research, Education and Extension Organization (AREEO), Rafsanjan, Iran

2- Plant Protection Research Department, Yazd Agricultural and Natural Resources Research and

Education Center, AREEO, Yazd, Iran ( $\triangle$ Corresponding author: moradi@pri.ir)

Received: 22.10.2017 Accepted: 23.04.2018

Moradi M. and Fani S. R. 2018. A review of aflatoxin in pistachio and control strategies. Plant Pathology Science 7(2): 22-33. DOI: 10.2982/PPS.7.2.22

Abstract: Aflatoxin contamination of pistachio nut is a health challenge that can affect the economic value of the largest Iranian non-oil exports. This potent hepatocarcinogen mycotoxin is produced by some species of Aspergillus, particularly by A. flavus, under certain conditions during fruiting, harvesting, transportation and storage. Infection of pistachio to the fungus in the orchard is the key factor in its contamination with aflatoxin. This situation occurs with the formation of early splited pistachios and mechanical damages that caused by biotic and abiotic factors. The environmental temperature and relative humidity and the moisture content of pistachio, during the different stages of pistachio production and processing, have significant roles in the incidence and distribution of fungal contamination as well as the increasing of aflatoxin production. The inhibition of these factors is possible with applying of some agronomic, mechanical, physical and biological methods. Orchard establishment based on principles of gardening like optimal plant spacing, uniformity of cultivars, good pruning, proper irrigation method and nutrition along with on time harvesting, proper processing and storage, can guarantee the production of a healthy and valuable product. Biological controls using nontoxinogenic strains of A. flavus and yeasts are also recorded as successful strategies for reducing the pistachio aflatoxin.

Key words: Aspergillus flavus, Pistachio, Mycotoxin

$$
\begin{aligned}
& \text { مرورى بر آفلاتوكسين در يسته و راهبردهاى مهار آن }
\end{aligned}
$$

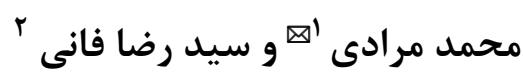

$$
\begin{aligned}
& \text { ا - يزوهشكده يُته، مؤسسه تحقيقات علوم باغبانى، سازمان تحقيقات، آموزش و ترويج كشاورزى، رفسنجان }
\end{aligned}
$$

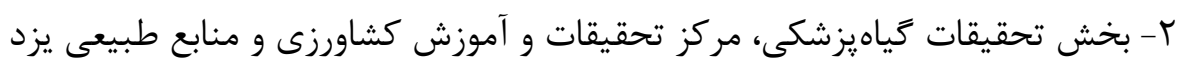

$$
\begin{aligned}
& \text { دريافت: • • }
\end{aligned}
$$

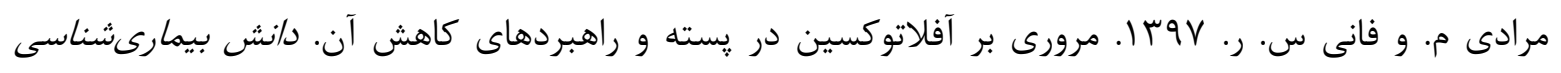

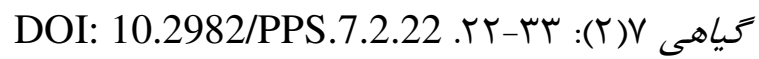


جُكيده: آلودگى ֶِته به آفلاتوكسين، يك جالش بهداشتى است كه ارزش اقتصادى بزرگترين محصول صادراتى غيرنفتى كشور را مىتواند تحت تأثير قرار دهد. اين زهرابهى بالقوه سرطانزاى كبد، توسط برخى گونههاى قارج Aspergillus بهويزه Aspergillus flavus تحت شرايط ويزه، در طول مدت تشكيل ميوه، در مرحله برداشت، حمل و نقل و انباردارى ممكن است توليد شود. عامل كليدى در بروز آلودگى يسته به آفلاتوكسين، قرار گرفتن مغز

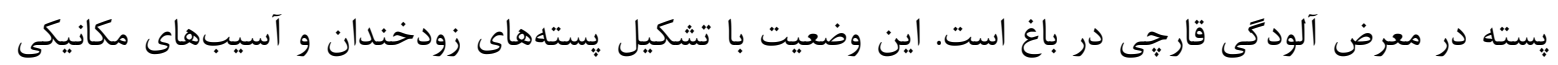
ناشى از عوامل زنده و غيرزنده روى مىدهد. دما و رطوبت نسبى محيط و ميزان رطوبت مغز يسته طى مراحل مختلف توليد و فرآورى يسته، در بروز و اشاعه آلودىى قارجى و افزايش توليد آفلاتوكسين نقش بهسزايى دارند. مهار عوامل يادشده با روشهاى مختلف زراعى، مكانيكى، فيزيكى و بيولوزيك امكانيذير است. احداث اصولى باغ و رعايت فواصل كاشت، يكنواختى ارقام و در مراحل بعدى، هرس، آبيارى صحيح و اصولى، تغذيه مناسب، برداشت به موقع، فرآورى و انباردارى صحيح مىتواند توليد محصولى سالم، بازاريسند و ارزشمند را تضمين نمايد. مهارزيستى با استفاده از سويههاى غيرتوكسينزاى A. flavus و مخمرها نيز راهبردى موفق در كاهش آفلاتوكسين يُته بوده است. وازههاى كليدى:Aspergillus flavus ، يُته ، زهرابهقارجى

سالانه • r درصد از محصولات غذايى توليد شده در دنيا توسط سموم قارجى يا ميكوتوكسينها آلوده مىشوند كه آلودكى به آفلاتوكسينها در اين بين سهم بيشترى دارنـد. خسـارت ناشـى از تخريسب مـواد غـذايى و محصـولات كشاورزى توسط اين توكسين بيش از · ا ميليون دلار در سال برآورد شده است (Ehrlich et al. 2003). پِته با

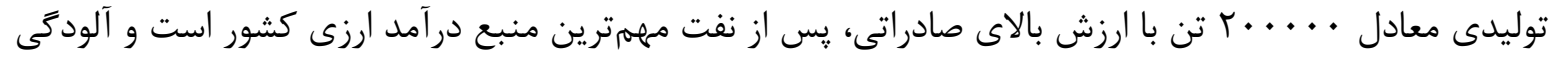
آن به آفلاتوكسين از سال • هـا جالش اصلى صادرات آن بوده است (Danesh et al. 1979). روشهـاى مختلفىى جهت مديريت آلودگى محصولات مختلف به آسيرزيلوس و يـا آفلاتوكسـين مانــد راهكارهـاى زراعى، مكـانيكى، فيزيكى و بيولوزيك توصيه شده است، كه هركدام بسته به مكان، زمان، نـوع محصـول، قابليـت كـاربردى بـودن و كارايى، معايب و محاسـن خـاص خـود را دارنــ Barkai-Golan and Paster 2008, Moradi and Hokmabadi (2011. محدوديتهاى بهداشتى و قوانين و مقرارت بين المللى مانع كاربرد بسيارى از روشهاى متـداول در مـورد קֶته شده است (Brans 2011). 


\section{ا-ويزَى هاى قارجهاى مولد آفلاتوكسين}

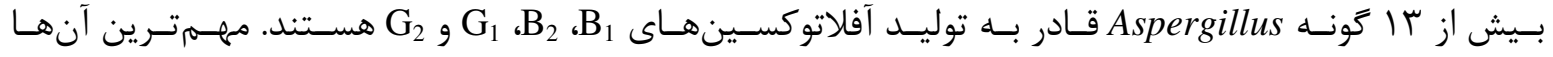
Aspergillus flavus Link است (Ito et al. 2001). اين كونه با شرايط دشوار محيطى به خوبى خود را وفق داده و به همين لحاظ، براكندكى جهانى داشته و از ساير كونهها اهميت بيشترى دارد. اين قارج قسمت عمــه خرخـهـ. زندگى خود را در خاك و مواد آلى كياهى و جانورى به صورت كندرو طى مى كند. ميسليوم، ساختار اصلى قارج در خاك هستند و بقاى طولانى مدت آن با توليد سختينه امكانيذير مىشـود (رحيمسزاده و صـدروى هوبـا). ايــن قارج علاوه بر آفلاتوكسين، \& ا انوع ميكوتوكسين ديكر نيـز مستوانـد توليـد كنــ (Amaike and Keller 2011). بيوسنتز آفلاتوكسين تحت شرايط محيطى مختلفى شامل نور، دما، اسيديته (pH)، منبع نيتـروزن، منبـع كـربن و

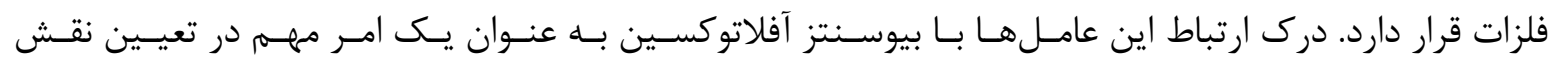
آفلاتوكسين در اكولوزى قارج حياتى است. اين امر مىتواند بـه شناسـايى مكـانهـاى هــف بـراى كنتـرل توليـــ آفلاتوكسين كمك كند. در ميان عاملهاى محيطى، نور در تنظيم بيـان زنهـاى بيوسـنتز آفلاتوكسـين و تشكيل ساختارهاى مقاوم مانند سختينه نقش دارد (Mirabolfathy et al. 2004) . شرايط اسيدى براى توليد آفلاتوكسين مطلوبتر از شرايط قليايى است و رونوشتهاى دسته رنى آفلاتوكسين در شرايط قليايى نسبت به شـرايط اسـيدى تحت تنظيم منفى است. فلزات به ويزه فلز روى از جمله عامل هاى مهم و ضرورى براى توليد آفلاتوكسين هسـتند (Keller et al. 1997). مخلوطى از عناصر مس، آهن و روى باعث افزايش بيان زن و توليد آفلاتوكسين مسشـوند.

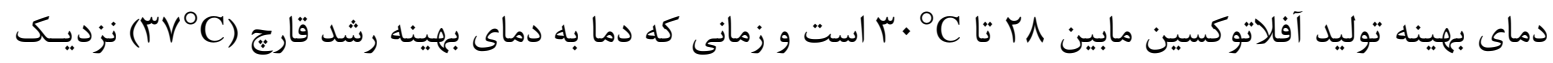
مىشود، توليد آفلاتوكسين كاهش مىيابد. اين اتفاق در دماهاى بايينتر از \1 نيز مىافتـد (Cuero et al. 2003) مطالعات نشان مىدهد وقتى دما از دماى بهينه رشد قارج بالاتر يا پايينتر مىرود، توليــ آفلاتوكسـين بـه صـورت خطى كاهش مي يابد. اين وضعيت به دليل كاهش رونويسى و بيـان برخى زنهـاى تنظيمسى مانـــ aflR اسـت 


\section{r- نحوه آلودكى گِسته به كونههاى Aspergillus و آفلاتوكسين}

براساس تحقيقات انجام شده، هات قارجهاى مولد آفلاتوكسين به صورت خاكزاد و هوازاد در خــاك، فضـاى بـاغ، اطراف محل فرآورى و انبار پِّته استقرار دارند، لذا آلوده شدن پِّته به Aspergillus و توليد آفلاتوكسـين توسـط آن در وهله اول قبل از برداشت و تحت شرايط باغى است (Moradi et al. 2010). يوست سبز در حالت طبيعى به عنوان مانعى فيزيكى، مغز يسته را در برابر عوامل خارجى به ويزه قارج آسيرزيلوس، محافظت مىنمايد، ولى تحـت تأثير عوامل مختلف اين يوست سبز ممكن است ترك خورده و مغز را در معرض هوا قرار داده، منجر به آلـودگى و توليد آفلاتوكسين گَردد. ترك خوردىى ميوه يسته، تحت تأثير عوامل مختلفـى مانـــد تـنش آبيـارى، رقـم، زمـان برداشت، آسيب يرندَان، بافت و ساختمان خاك، جگَونكى تعادل عناصر غذايى در خاك و برخى عوامل ديكر است (Moradi and Hokmabadi 2011) باعث استقرار هاگ موجود در هوا روى مغز گردد يايه گذار آلودگىهاى اوليه است. فرآورى، انباردارى و حمل و نقل نامناسب مىتواند منجر به تشديد رشد قارج و افزايش توليد آفلاتوكسين شود. تحقيقـات انجـام شـده در خصـوص اكولوزى گَونهاى آسيرزيلوس در باغهاى يسته نشان داده است كه جمعيت گونههاى آسيرزيلوس در طول سال با

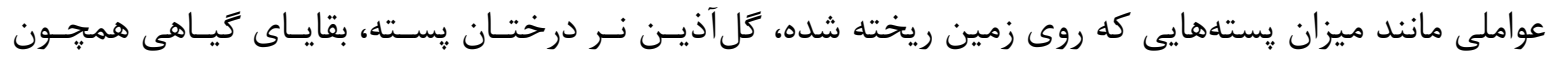
نخالههاى حاصل از فرآورى ميوه يسته (شكل J ())، دور آبيارى، عمليات باغبانى و كودهاى حيوانى در ارتباط اسـت

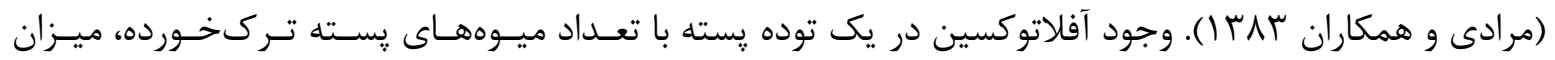
آلودگى به آفات، خصوصيات ظاهرى و آسـيب ديـدگى يوسـت اسـتخوانى در ارتبـاط اسـت ( Ghahdarijani and 2006 Javanshah به آفات، جوند Fان، برهمكنش ميكروبى، تركيب گازهاى جوى انبار، رطوبت محيط و رطوبت ميوه يسـته در زمـان فرآورى، انباردارى و حمل و نقل هستند (مرادى و همكاران \&qس (). 
تراكم بهينه درختان در باغ: تراكم درخت در واحد سطح روى نفوذ نور، تهويه مناسب، رطوبت نسبى محسيط و ترك خوردكى ميوه يسته تأثير دارد. فاصله Y-Y متر بين درختان و V-4 متر بين رديفها بسته به نوع خاك و رقم توصيه شده است (شكل A ()). نوع رقم: ارقام پِته از نظر زمان و يكنواختى رسيدن، ريزش ميوههاى رسـيده قبـل از برداشـت و درصـد تـرك خوردىى با هم تفاوت دارند. در مناطقى كه بارندگى اواخر تابستان دارند، بهتر است ارقـام زودرس مانــد فنـدقى و در مناطق داراى تابستانهاى خنكى به دليل طول كشيدن رسيدن ميوه تا اواخر مهـر و احتمـال بارنـدگى در ايـن زمان، لازم است ارقام دير رس كاشته شود. از كاشت مخلوط ارقام يسـته خـوددارى شـود جــون در ارقـام زودرس، طول دوره رشد نسبت به ارقام ديررس كوتاهتر است و تأخير در زمان برداشت باعث افزايش آلودگى مى از نظر عارضه زودخندانى نيز با يكديكر متفاوتند. يسته زودخندان حداقل ها روز زودتر از موعد اصلى خندان شده و شيار خندانى يوست سبز در امتداد شيار خندانى يوست استخوانى است (شـكل B (). ايسن نـوع پــــه بـه دليـل مدت زمان زيادى كه مغز آن در معرض هاگهاى قارج است، كانون آلودگى به شمار مسىرود. نـوع ديخـرى از ايـنـ "ِتهاى نامطلوب نيز وجود دارد كه دجار شكاف خوردگى نامنظم هستند. در اين نوع، ترك خوردگى يوست سبز در امتداد شيار خندانى يوست استخوانى نيست (شكل C (). انواع خسارتهاى مكانيكى كه توسط آفات ميـوهخـوار و يرندكان به يُستهاى در حال تشكيل وارد مىشود نيز مىتواند در ايجاد كانونهاى آلودگى نقـش مهمـى داشـته باشد (شكل D (1). ارقام جوادآقايى و سيف الدينى بيشترين و رقم قزوينى كمترين زودخندانى را دارد. زمـان ظهـور يستههاى زود خندان از سالى به سال ديگر و از منطقهاى به منطقه ديگر تفـاوت زيـادى دارد و در بـين سـه رقـم تجارتى يسته اوحدى، كله قوجى و احمد آقايى، در رقم كله قوجى يستههاى زودخندان، زودتر تشـكيل مسىشـوند. بيشترين درصد تشكيل يستههاى زودخندان در فاصله زمانى ها روز قبل از برداشت اتفاق مىافتد. حساسيت ارقام يسته نسبت به قارج و ميزان توليد آفلاتوكسين روى آنها نيز متفاوت است. ارقام احمدآقايى و اوحسـدى بيشـترين و اكبرى و كله قوجى كمترين حساسيت را به قارج دارند. از طرفى ارقام شاهِيند و عباسعلى داراى بيشترين و ارقـام

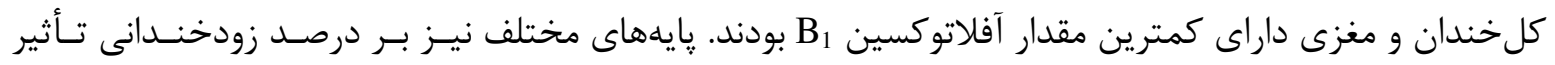


دارند به طورى كه پايههاى بنه و آتلانتيكا داراى بيشترين درصد و پايـه اهلى داراى كمتـرين درصـد زودخنـدانى هستند (Moradi and Hokmabadi 2011).

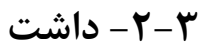

هرس: هرس فرم و باردهى از اصول اوليه مورد توجه در يرورش درختان يسته است لذا ايجاد درختان تكتنه و بـا ارتقاع تنه • rا-_.· سانتيمتر و به شكل جامى باز ضرورت دارد. به منظور كاهش آلودىى ميـوه در بـاغ از طريـق عدم تماس شاخههاى درخت با زمين و آب آبيارى، هر ساله بايستى شاخههاى خشك، پاجوشها و شاخههايى كـهـ

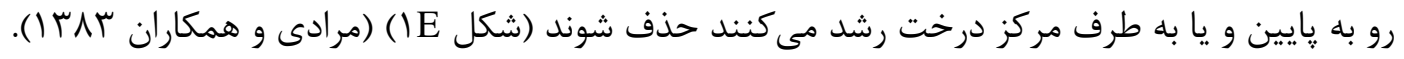
آبيارى: تنش آبيارى در اواخر بهار مىتواند موجب افزايش زودخندانى شود. نوع آبيارى در اين مورد نقشى نـدارد.

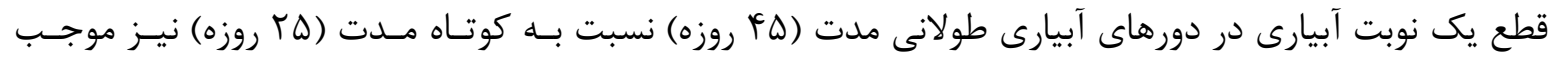
دوبرابر شدن زودخندانى مىشود. لذا بايستى اولاً دور آبيارى براساس بافت خاك، كيفيت آب، شـورى خـاك، سـن درخت و روش آبيارى انتخاب كردد، ثانياً آبيارى به طور منظهم انجام شده و از قطع آبيـارى در اواخـر فصـل بهـار خوددارى شود و ثالثاً آبيارى براساس نياز آبى كياه تنظيم شود. در صورتى كه به دليـل كمبـود آب امكـان آبيـارى براساس نياز آبى نيست، بهتر است آبيارى به طور يكنواخـت و بـا دور آبيـارى مـنظم در طـول فصـل انجـام شـود

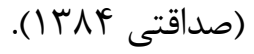

تغذيه: عدم تعادل غذايى در تركخوردگى يوست سبز ميوه نقش مهمى دارد. تجزيه كامل يوست سبز بستههـاى تركخورده و سالم حاكى از يايين بودن عناصر پِتاسيم و آهن و بالا بودن فسفر و روى در يستههاى تـرك خـورده بوده است. عدم استفاده از كودهاى آلى مثل كود مرغى نيز موجـب افزايش درصــ زودخنــانى و تـرك كـوردىى

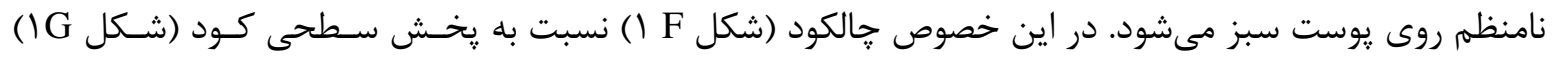

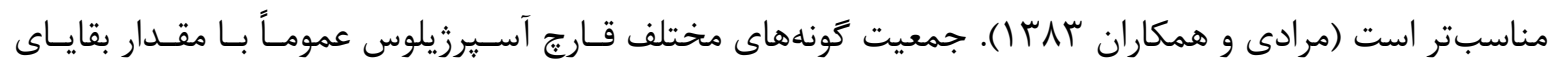
كياهى، ضايعات حاصله از فرآورى ميوه پسته (شكل J ( ) و كودهاى حيوانى در ارتباط استـ و در ٍـاييز و زمسـتان افزايش مىيابد. از اين رو ضمن رعايت بهداشت باغ، در صورتى كه استفاده از اين مواد براى اصلاح بافت خاك يا 

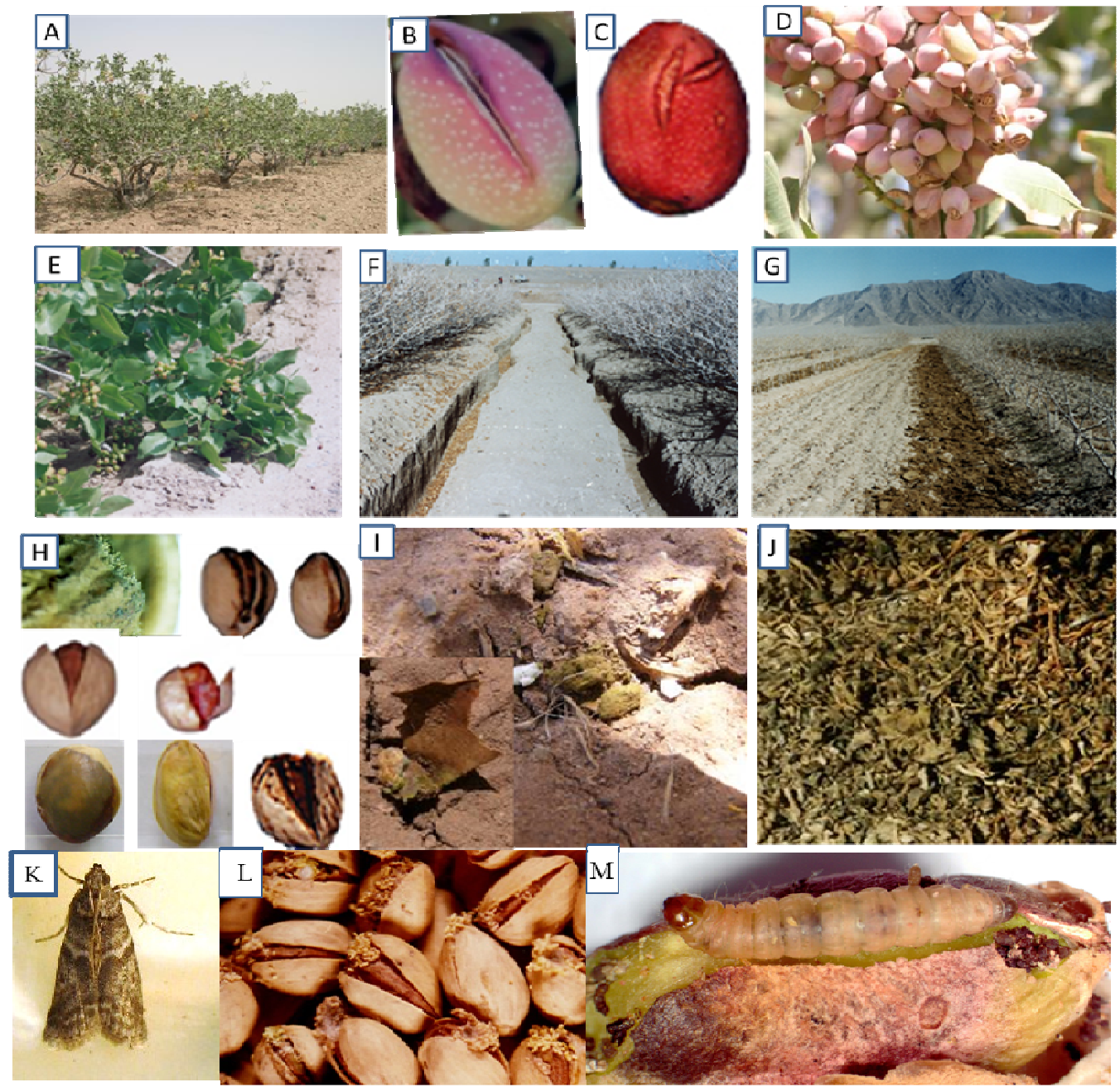

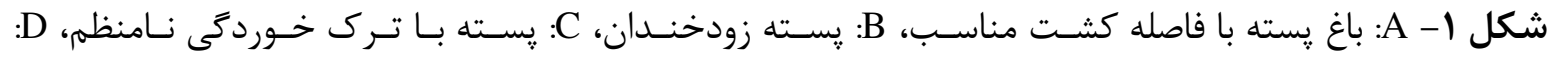
يستههاى آسيب ديده از آفات ميوهخوار، E: شاخههــاى هـرس نشـده در تمـاس بــا خـاك، F: اسـتفاده صـحيح از كودهاى حيوانى به شيوه جالكود، G: كوددهى نادرست با يخش سطحى، H: انواع يستههـاى غيرطبيعى و لكـهدار در مقايسه به يسته طبيعى (رديف وسط، ج̋)، II: يخش دانه گَندم كلنيزه شده با جدايـه غيرتوكسـينزا در سـطح خاك، J: نخالهها يا ضايعات حاصل از فرآورى ميوه يسته آلـوده شـده بـه قـارج Aspergillus در بـاغ, K-M : لارو،

$$
\text { حشره كامل و خسارت شب يره خرنوب روى ميوه يسته (منبع عكس: مهدى بصيرت، يزوهشكده يسته) }
$$

Figure1. A: Pistachio orchard with proper tree spacing, B: Early splitting pistachios, C: Cracking of Pistachio nuts, D: pistachio damage by pests and birds, E: Branches in contact with soil surface, F: Application of animal manures in fertilizer channels, G: Incorrect application of animal manure in soil surface, H: Aflatoxin contaminated pistachios, I: Application of atoxigenic isolate of Aspergillus flavus in the pistachio orchards using colonized wheat seeds, J: The pistachio rubbish contaminated with Aspergillus species, K-M: Larvae, adult and damage of carb moth on pistachios fruit (source: Mehdi Basirat, Pistachio Research Center). 
تغذيه در نظر كرفته شود، بهتر است بهصورت جـالكود باشـند و از پخـش سـطحى آنهـا خـوددارى شـود (مـرادى

.$(1 \mathrm{HNT}$

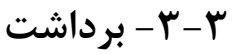

با توجه به نوع رقم، بافت خاك و شرايط آب و هوايى منطقه توصيه مىشـود محصـول هـر رقهم در زمـان مناسـب برداشت كردد و از نكَهدارى محصول روى درخت به دليل افزايش وزن ميوه، افزايش درصد خندانى، افززايش رشـد مغز، حجم زياد محصول يا سطح باغ و كمبود امكانات فرآورى جلوكيرى شود. زمان مناسب برداشت مـوقعى اسـت كه بين · V Vا VD درصد ميوههاى هر درخت داراى نشانهاى ظاهرى رسيدگى نظير تغيير رنخ يوست نرمرويى و سهولت يوستدهى هستند. تحقيقات نشان داده با نزديك شدن به زمان برداشت تراكم جمعيـت قـارجهـاى مولـــ

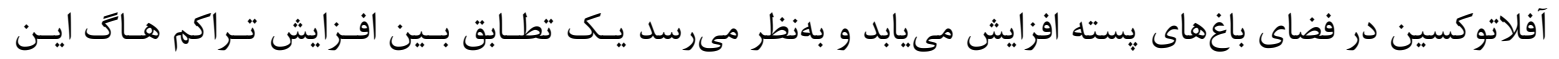

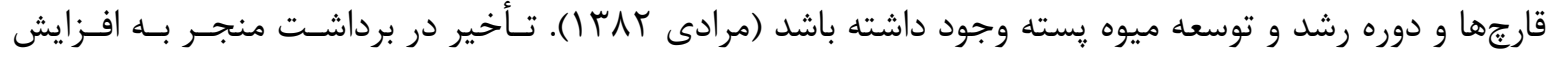

$$
\text { آلودكى به آفلاتوكسين مىشود (فانى و همكاران بوبr ). }
$$

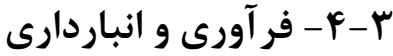

نتايج حاصل از بررسى آلودگى ترمينالهاى مختلف به قارجهاى Aspergillus niger Tieghو A. flavus نشان مىدهد كه آلودگى تحت تأثير عوامل مختلفى است. نوع ترمينال (سنتى يا مكانيزه)، قسمتهاى مختلف ترمينال و نوع پسته ورودى از جمله اين عوامل هستند. فراوانى بستههاى تركخورده (زودخندان و تركخورده نامنظم با يوست سبز خشك و خروكيده)، يستهاى روى زمين ريخته شده و پِتهاى در تماس با سطح زمين در آلودىى

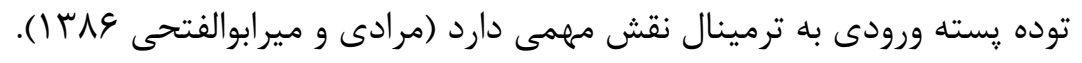
بديهى است ترمينالهاى مكانيزه و نيمه مكانيزه به دليل آلودگىهاى بايينتر ٍِته خروجى به ميكرواركانيسهمهـا

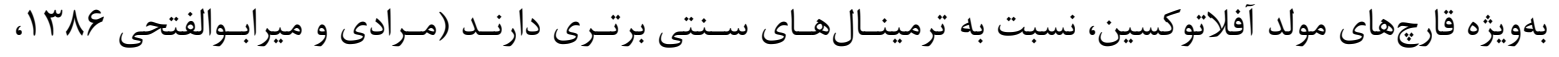
Moradi et al. 2010 . تحقيقات انجام شده نشان مىدهد كر جه شرايط براى آلودىى و توليد آفلاتوكسـين در بـاغ مهيا است ولى شرايط فرآورى در ترمينال هاى مكانيزه و نيمه مكانيزه و همجنين انباردارى براى توليد آفلاتوكسين 
مناسب نيست. با اين حال جنانجه در مراحل بعدى نكَهدارى يا حمل و نقـل، شـرايط مناسـب باشـــ بـا توجـهـ بــهـ

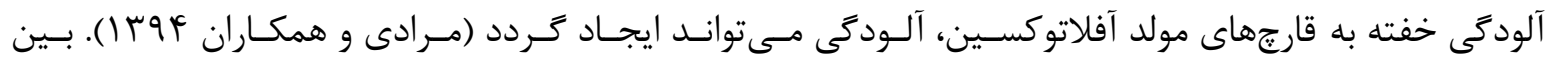
لكهدارشدن يوست استخوانى و آلودكى آنها به قارجهاى Aspergillus ارتبـاط وجـود دارد و خصوصـيات ظـاهرى

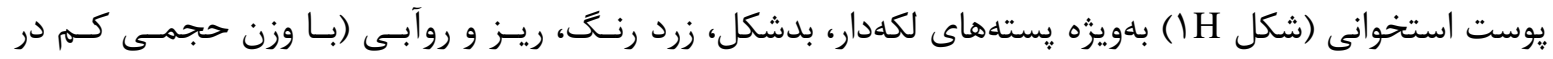
مقايسه با پِستههاى زير آبى) مىتواند بهعنوان شاخص مهم آلودَى به آفلاتوكسين جهت جداسـازى از پسـتهــاى

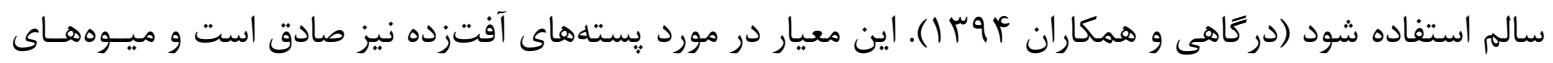
آلوده به شب يره خرنوب (شكلهاى K-M () غالباً آلودگى بالايى به آفلاتوكسين دارد (فانى و همكاران بوج ا). ب- - - - مهارزيستى آفلاتوكسين يكى از روشهاى مؤثر و كاربردى در زمينه كاهش خطر آلودىى محصولات كشاورزى و يا فراوردهاى آنها، استفاده از عوامل مهارزيستى مانند سويههاى غيرتوكسينزاى A. flavus مخمرها، باكترىها و اكتينوميستها است. مهارزيستى با بهكاركيرى سويههاى غيرتوكسينزاى A. flavus بيشترين موفقيت مزرعهاى را در كاهش آلودگى هاى آفلاتوكسينى در پنبه، بادامزمينى، ذرت و يسته از خود نشان داده است. سويههاى غيرتوكسينزايى كه در خاك استفاده شدند كنج اكولوزيكى سويههاى توكسينزا را تسخير مى كنند؛ بنابراين، اين سويهها توانيى رقابت و جايكزينى با سويههاى توكسينزا را داشته و سطح آفلاتوكسين را بطور قابل توجهى كاهش مىدهند (Amike and Keller 2011). در اين روش يكبار در سال در اواخر بهار يا اوايل تابستان دانهاى غلهاى كه با سويههاى غيرتوكسينزا مايهزنى شدهاند در باغ يخش مىشوند (شكل II). بعد از آبيارى، قارج رشد و هاگزايى كرده و جمعيت آن غالب خواهد شد (Doster 2014). با توجه به يزوهشهاى انجام كَفته از اين روش در باغهاى يسته كشور نيز مى توان استفاده كرد (فانى و همكاران ץو با، Fani et al. 2014 ).

\section{نتيجهَيرى و پييشنهاد}

آلودَى ميوه يسته به انواع آفلاتوكسين، كه اغلب توسـط قـارج خـاكزاد و هـوازاد Aspergillus flavus بـه وجـود مى آيد به عنوان يك جالش بهداشتى، تحت شرايط خاص، در طول مدت تشكيل ميوه، در مرحله برداشت، حمـل و 
نقل و انباردارى ايجاد ميكردد. از عاملهاى مههم در اين زمينه پستههاى ترك خورده و آسيبهاى مكانيكى ناشى از از عوامل زنده و غيرزنده است كه تحت تأثير عوامل مديريتى، آبيارى، تغذيـهـ و زمـان برداشـت اسـت. مــيريت آلودكى با روشهاى مختلف زراعى، مكانيكى، فيزيكسى و زيسـتى امكـانيـذير اسـت. مهارزيسـتى آفلاتوكسـين بـاــا استفاده از جدايههاى غيرتوكسينزاى A flavus و مخمرها نيز به عنوان راهبــردى مـؤثر در ايـن زمينـهـ بِيشــهاد

$$
\text { مىشود. }
$$

\section{References}

\section{منابع}

ا. دركاهى ر.، مرادى م. و فانى س. ر. عqז ا. ارزيابى ميزان آفلاتوكسين B در بخشهاى مختلف ميوه

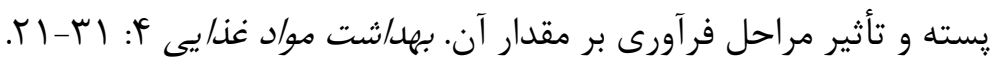
ז. رحيمىزاده م. و صدروى م. لهوبا. معرفى هشت گونهى مفيد Aspergillus ، دانش بيمارىشناسى

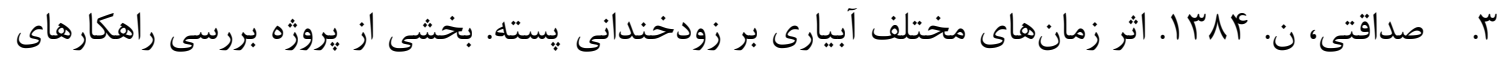
عملى جهت حذف يا كاهش آفلاتوكسين. موسسه تحقيقات پِته كشور. كزارش نهايى طرح تحقيقاتى مؤسسه تحقيقات سֶته كشور، Tr ص.

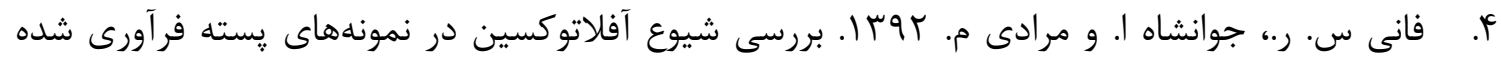

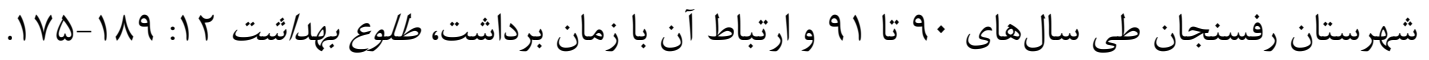
ه. فانى س. ر.، مرادى م.، تاجآبادىيور ع.، در كاهى ر. و ميرابوالفتحى م. باوسا، نقش زودخندانى در آلودگى

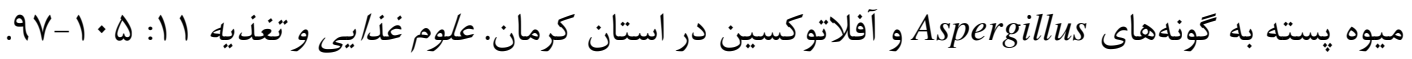
9. فانى س. ر.، مرادى م.، زمانىزاده ح. ر.، ميرابوالفتحى م. و يروبست ك. זوجا. يراكنش سويههاى

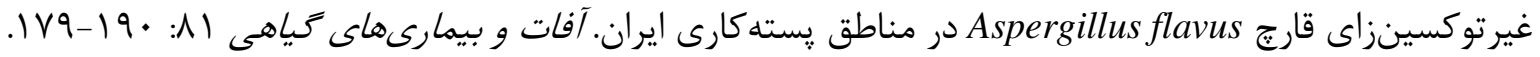

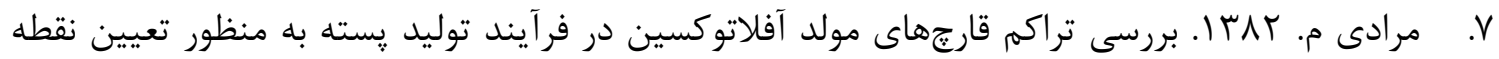
شروع آلودىى و كنترل آن. كزارش نهايى طرح تحقيقاتى مؤسسه تحقيقات يسته كشور، شماره 1Y/999، FV ص. 


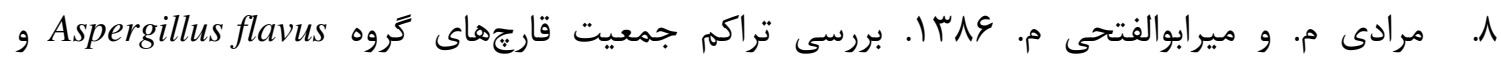

$$
\begin{aligned}
& \text { Aspergillus niger }
\end{aligned}
$$

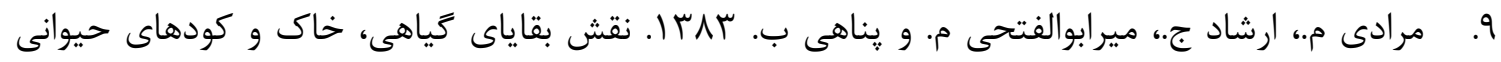

$$
\begin{aligned}
& \text { روى تراكم جمعيت قارجهاى گروه Aspergillus flavus niger در باغهاى يسته استان كرمان. }
\end{aligned}
$$

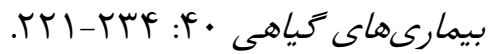

$$
\begin{aligned}
& \text { • . . مرادى م.، حكمآبادى ح. و فانى س. م. \&q廿ا. بررسى عوامل مؤثر بر رشد قارجى و توليد آفلاتوكسين در }
\end{aligned}
$$

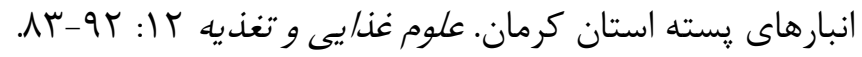

$$
\begin{aligned}
& \text { II. مرادى م.، فانى س. ر. و معصومى ح. سوسا. نوسان جمعيتهاى متعلق به بخشهاى فلاوى و نيخرى }
\end{aligned}
$$

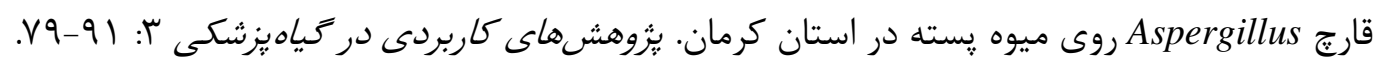

12.Amaike S. and Keller N. P. 2011. Aspergillus flavus. Annual Review of Phytopathology 49:107133.

13.Barkai-Golan R. and Paster N. 2008. Mycotoxins in fruits and vegetables. Burlington, Academic Press. 160P.

14.Brans H. 2011. Food and Agricultural Import Regulations and Standards Narrative. USDA Foreign Agricultural Service, Global Agriculture Information, 42p.

15.Cuero R., Ouellet T., Yu J. and Mogongwa N. 2003. Metal ion enhancement of fungal growth, gene expression and aflatoxin synthesis in Aspergillus flavus: RT-PCR characterization. Journal of Applied Microbiology 94:953-961.

16.Danesh D., Mojtahedi H., Barnett R. and Cambell A. 1979. Correlation between climatic data and aflatoxin contamination of Iranian pistachio nuts. Phytophthology 69:715-716.

17.Doster M. A., Cotty P. J. and Michailides T. J. 2014. Evaluation of the atoxigenic Aspergillus flavus strain AF36 in pistachio orchards. Plant Disease 98:948-956.

18.Ehrlich K. C., Montalbano V. G. and Cotty P. J. 2003. Sequence comparison of aflR from different Aspergillus species provides evidence for variability in regulation of aflatoxin production. Fungal Genetics and Biology 38:63-74.

19.Fani S. R., Moradi M., Probst C., Zamanizadeh H. R., Mirabolfathy M., Haidukowski M. and Logrieco A. F. 2014. A critical evaluation of cultural methods for the identification of atoxigenic 
Aspergillus flavus isolates for aflatoxin mitigation in pistachio orchards of Iran. European Journal of Plant Pathology 140:631-642.

20.Ghahdarijani M. M. and Javanshah A. 2006. Distribution of aflatoxin in processed pistachio nut terminals. Acta Horticulture (ISHS) 726:431-436.

21.Ito Y., Peterson S. W., Wicklow D. T. and Goto T. 2001. Aspergillus pseudotamarii, a new aflatoxin producing species in Aspergillus section Flavi. Mycological Research 105:233-239.

22.Keller N. P., Nesbitt C., Sarr B., Phillips T. D. and Burow G. B. 1997. pH regulation of sterigmatocystin and aflatoxin biosynthesis in Aspergillus spp. Phytopathology 87:643-648.

23.Liu B. H. and Chu F. S. 1998. Regulation of aflR and its product, $A f l$ R, associated with aflatoxin biosynthesis. Applied and Environmental Microbiology 64:3718-3723.

24.Mirabolfathy M., Ghadarijani M. M. and Waliyar F. 2005. Variability in aflatoxicogenic potential and sclorotial production of $A$. flavus in pistachio in Iran. In IV International Symposium on Pistachios and Almonds 726:619-626.

25.Moradi M. and Hokmabadi H. 2011. Control of Mycotoxin Bioactives in Nuts: Farm to Fork. Pp. 253-273. In Ö. Tokusoglu (ed), Fruit and Cereal Bioactives Sources, Chemistry, and Applications CRC Press.

26. Moradi M., Hokmabadi H. and Mirabolfathy M. 2010. Density fluctuations of two major Aspergillus species airborne spores in pistachio orchards growing regions of Iran. International Journal of Nuts and Related Science 1:60-70

27.Rahimizadeh M. and Sadravi M. 2017. Eight useful Aspergillus species. Plant Pathology Science 6:22-32. (In Persian with English Abstract). 